\title{
Detection of Helicobacter pylori in dental plaque of Mexican children by real-time PCR
}

\author{
J. A. Valdez-Gonzalez ${ }^{1,2}$, P. C. Mares-Moreno ${ }^{3,4}$, M. J. Kowolik ${ }^{5}$, J. Vargas-Villlarreal ${ }^{6}$, \\ F. Gonzalez-Salazar, ${ }^{6,7}$ M. A. De la Garza-Ramos ${ }^{2,4^{*}}$ \\ ${ }^{1}$ Department of Epidemiology and Biostatistics, University of California San Francisco, San Francisco, USA \\ ${ }^{2}$ Centro de Investigación y Desarrollo en Ciencias de la Salud, Universidad Autónoma de Nuevo León, Gonzalitos Norte y Carlos \\ Canseco, Mitras Centro, Monterrey, Mexico \\ ${ }^{3}$ Centro Medico Nacional Del Noreste Hospital de Especialidades \#25 IMSS, Monterrey, Mexico \\ ${ }^{4}$ Posgrado de Odontopediatria, Universidad Autonoma de Nuevo Leon, Eduardo Aguirre Pequeño y Silao, Colonia Mitras Centro, \\ Monterrey, México; *Corresponding Author: fgonz75@hotmail.com \\ ${ }^{5}$ Department of Periodontics and Allied Dental Programs, Indiana University School of Dentistry, Indianapolis, USA \\ ${ }^{6}$ Centro de Investigaciones Biomedicas del Noreste, IMSS, Monterrey, México \\ ${ }^{7}$ Departamento de Ciencias Basicas, División de Ciencias De La Salud, Universidad de Monterrey, San Pedro Garza García, México
}

Received 21 November 2013; revised 30 December 2013; accepted 7 January 2014

Copyright (c) 2014 J. A. Valdez-Gonzalez et al. This is an open access article distributed under the Creative Commons Attribution License, which permits unrestricted use, distribution, and reproduction in any medium, provided the original work is properly cited. In accordance of the Creative Commons Attribution License all Copyrights (C) 2014 are reserved for SCIRP and the owner of the intellectual property J. A. Valdez-Gonzalez et al. All Copyright (C) 2014 are guarded by law and by SCIRP as a guardian.

\section{ABSTRACT}

Dental plaque in adult patients is well identified as a reservoir for Helicobacter pylori. This question still remains unclear in children. The aim of this study is to identify the presence of this bacterium in dental plaque of Mexican pediatric patients, using Real Time Polymerase Chain Reaction (qPCR). Forty patients from 2 to $\mathbf{1 1}$ years without dyspeptic symptoms were enrolled. Samples were collected from the subgingival space of the lingual side of the lower molars and cultured in selective medium. Therefore, qPCR analysis was conducted. According to the results obtained in this study, it was found that $35 \%$ of the pediatric population who participated tested qPCR positive for the presence of $H$. pylori in dental plaque samples. No significant associations were detected among isolation rate by gender or age. We found that dental plaque may be a reservoir for $\boldsymbol{H}$. pylori. However, more research is needed to establish the way of the infection of pediatric population.

\section{KEYWORDS}

Helicobacter pylori; Oral Pathology; Children; Real Time Polymerase Chain Reaction; Anaerobic Bacteria

\section{INTRODUCTION}

Gastric cancer is one of the most common deadliest types [1] and it's directly related to cronic infection of Helicobacter pylori [2-6]. Since 1984, Marsall and Warren associated $H$. pylori to chronic gastritis and peptic ulcers [7] and the International Agency for Research on Cancer classified it as a type I carcinogen in human beings [8].

There are many theories trying to explain the way $H$. pylori colonizes the stomach $[9,10]$ and dental plaque is one of the recognized sites as a reservoir [11]. Positive findings on dental plaque in adults have been documented $[12,13]$. However, other studies show disagreeing results because they have failed in isolating the bacteria [14-16].

Prevalence studies of $H$. pylori infection have demonstrated an increase in the general population and an early exposure to the bacterium is the factor that explains why this organism is found in various age groups. Although the infection can be asymptomatic in children, sometimes it is reported to be accompanied by recurrent abdominal pain and dyspepsia symptoms [17-19]. In developed countries as Mexico, the prevalence of $H$. pylori seems to be lower in children and increases progressively with age [20]

The diagnosis of $H$. pylori is complex and is mostly done with the Urease test, which is poorly sensitive and leads to false negative results [21,22]. New studies have showed that the most feasible method for early detection 
is real time polymerase chain reaction (qPCR). Using this technique, it has been possible to detect $H$. pylori in samples of dental plaque, canker sores, saliva, gastric acid and feces offering a better alternative for clinical diagnosis [15,23,24].

The aim of this work was to determinate the frequency of $H$. pylori in dental plaque in children by a molecular diagnosis method called qPCR.

\section{MATERIALS AND METHODS}

This cross sectional study was conducted from July to August 2013 during follow-up visits from the Clinic of Pediatric Dentistry at the University of Nuevo Leon, Mexico. Forty subjects were enrolled and the inclusion criteria were: children from 2 to 11 years old, any gender, and apparently healthy. The exclusion criteria were: 1) actual history of antibiotic usage or during the previous 2 months, 2) systemic disease, and 3) abdominal pain. This protocol was registered in the institutional research committee. Prior the sampling the parents or guardian of the patient signed an informed consent form and declared their willingness to allow the use of the samples and their anonymous data for research purposes.

Sampling was by convenience according patients arrive to clinic until completed the sample size. A sterile wooden stick of $1 \mathrm{~mm}$ in diameter was used to get the dental plaque sample; it was modified on one end to create an active part as a shovel. The sample was taken from the lingual sulcus in the lower molars and placed in a microcentrifuge tubes containing: $150 \mu \mathrm{l}$ bovine serum and $350 \mu 1$ of trypticase soy.

Samples were grown on Campy Agar (10\% sheep blood, Amphotericin, Cephalothin, Trimethoprim, Vancomycin and Polymyxin B). $200 \mu \mathrm{l}$ of the sample were placed on the center of a Petri plate and incubated under microaerophilic conditions using a GasPak $\mathrm{CO}_{2}$ jar system (Becton Dickinson, USA). After 5 days, the bacteria were collected by scraping the colonies from the agar and cultured under the same conditions stated above for 3 days.

The DNA from the harvested bacteria was extracted by using Wizard ${ }^{\circledR}$ Genomic DNA Purification Kit (cat A1120 Num. Promega, USA) following the manufacturer's instructions. The samples were stored at $-20^{\circ} \mathrm{C}$ until use for Real-Time Polymerase Chain Reaction (qPCR). The specific oligonucleotides probes were previously designed using the Primer Express 3.0 program (Applied Biosystems, USA) and selected for the $16 \mathrm{~S}$ ribosomal subunit from $H$. pylori.

The qPCR reaction conditions was assessed 96-well plates, filled with $2.5 \mu \mathrm{l}$ of each sample DNA, $5 \mu \mathrm{lde}$ PCR reaction mixture (Universal TaqMan Master kit Probe I, Roche, Germany) and $0.150 \mu \mathrm{l}$ of the designed primers. For the positive and negative controls, instead of sample DNA, were added pure DNA from the strain $43054 \mathrm{H}$. pylori and sterile water, respectively.

qPCR was carried out in a Light-Cycler 408II system (Roche, UK), programmed with the detection mode of HRM Dye, block of 96 and a reaction volume of $10 \mu \mathrm{l}$. The three stages were: pre-incubation at one cycle, fifty amplification cycles with quantification analysis mode and the cooling cycle.

The pre-incubation was conducted at a temperature of $95^{\circ} \mathrm{C}$, at hold for 5 minutes and a ramp of $4^{\circ} \mathrm{C} / \mathrm{S}$, the amplification was carried out with three different temperatures: $95^{\circ} \mathrm{C}$ at a hold of 10 seconds and a ramp of $4^{\circ} \mathrm{C} / \mathrm{S}$, $55^{\circ} \mathrm{C}$ at a hold of 15 seconds and a ramp of $2^{\circ} \mathrm{C} / \mathrm{S}$, and finally at $72^{\circ} \mathrm{C}$ at hold of $10 \mathrm{sec}$, a ramp of $4^{\circ} \mathrm{C} / \mathrm{S}$ and a single acquisition mode. The cooling program was at temperature of $40^{\circ} \mathrm{C}$, a hold for 30 seconds and a 2 seconds ramp.

The sample size of 40 subjects was calculated using Stata IC12 with a power of $80 \%$ and a confidence level of 95\%. All data were stored in an Excel Microsoft Database. The data were analyzed by SPSS IBM Statistics v19. Proportion of isolations of $H$. pylori was determined and next, the association of isolation according genre were determined by Chi square. Differences in the mean age according isolation were evaluated by t student test. Values were considered statistically significant if $\mathrm{p}$ value $<0.05$.

\section{RESULTS}

The study population consisted of 40 healthy pediatric patients, 13 females (32.5\%) and 27 males (67.5). The mean age was $5.35+2.23$, mode and median were 5 . The distribution of patients according to age is shown in Table 1 where the range is 9 , while the minimum and maximum were 2 and 11 years respectively.

The prevalence of $H$. pylori isolation was $35 \%$ in the total sample, while the isolation frequencies by age and gender are presented in Tables 1 and 2 respectively.

There is no significant association within the occurrences of isolation and age $(\mathrm{p}=0.32)$ (Table 1$)$, the mean age of patients with and without isolation (p. = 0.14 ) (Table 3) and between gender and isolation of $H$. pylori $\mathrm{p}=0.09$ (Table 2 ).

\section{DISCUSSION}

The infection with $H$. pylori is considered carcinogen and is recognized as the primary cause of gastric cancer [8]. Several studies have concluded that $H$. pylori is existent in the oral cavity and proposed that the mouth could be the source of infection and reinfection after eradication treatments for stomach infections [11-13]. More specialized studies postulate that $H$. pylori exists in peri- 
odontal pockets, because it re-creates an excellent atmosphere for microaerophilic and anaerobic microorganisms. However, many authors have concluded that the oral cavity is not a reservoir for this bacterium [14-16] and these contradictory results can be explained by differences in the studied population, the possible contamination of the sample, collection methods and poorly sensitive diagnostic techniques.

In this study, 35\% of the children tested positive for $H$. pylori. All the subjects appeared otherwise healthy, and none of them reported any gastrointestinal disease. Studies in non-dyspeptic pediatric population are consistent with our results obtaining similar prevalence rates $[25,26]$, unlike when conducted in adult populations where it was only possible to isolate $H$. pylori in the dyspeptic patients [27]. Our results do not show association between age and $H$. pylori isolation, and most of the patients under 5 years have higher isolation rates 11/17 (64.7\%) than those over 5 years 3/9(33.3\%) (Table 1), opposing with Oliveira et al. [28] and the prevalence was $16 \%$ in patients less than 2 years of age, $37 \%$ in children from 3 to 5 and $64 \%$ in patients 15 to 18 years old.

The plaque sample was collected from the lingual sulcus in the lower molars because it was not constantly swept by the salivary flow and was a half anaerobic zone. We consider this a niche with the appropriate $\mathrm{pH}$, redox potential, and nutrient availability to sustain the bacteria [29]. In this study, we cultured the bacteria in specific medium, in order to eliminate other pathogenic bacterium. Detection of $H$. pylori has been achieved by several methods, some effective and others with low sensitivity, but the qPCR is the most suitable for detecting low numbers of $H$. pylori in the oral cavity [15]. The primer used for qPCR is specific for $H$. pylori and eliminates the possibility of false-positive results. The highly sensitive 16S rRNA gene was used for the DNA amplification. This cellular component has been shown to be suitable for demonstrating phylogenetic diversity of bacteria [30]. Although sensitivity is tenfold more than other PCR methods, this nonspecifically amplifies human DNA [23, 31].

In conclusion, this study strongly supports the hypothesis that the mouth of children may be a reservoir for $H$. pylori. Further studies will be required to confirm the importance of any relationship between oral and gastric strain and possible routes of transmission. It is necessary to pay attention to dental plaque as a possible second reservoir for $H$. pylori colonization.

\section{ACKNOWLEDGEMENTS}

The authors would like to thank to the Consejo Nacional de Ciencia

Table 1. Shows distribution of patients by age and isolation of H. pylori.

\begin{tabular}{|c|c|c|c|c|c|c|}
\hline \multicolumn{7}{|c|}{ Isolation H. pylori } \\
\hline \multirow{2}{*}{$\begin{array}{c}\text { AGE } \\
\text { (Years) }\end{array}$} & \multicolumn{2}{|c|}{ NEGATIVE } & \multicolumn{2}{|c|}{ POSITIVE } & \multirow{2}{*}{ Sum } & \multirow{2}{*}{$\mathrm{p}$ value } \\
\hline & $\mathrm{n}$ & $\%$ & $\mathrm{n}$ & $\%$ & & \\
\hline 2 & 1 & 100 & 0 & 0 & 1 & \multirow{10}{*}{${ }^{*} 0.32$} \\
\hline 3 & 7 & 87 & 1 & 13 & 8 & \\
\hline 4 & 2 & 40 & 3 & 60 & 5 & \\
\hline 5 & 7 & 50 & 7 & 50 & 14 & \\
\hline 6 & 3 & 100 & 0 & 0 & 3 & \\
\hline 7 & 1 & 100 & 0 & 0 & 1 & \\
\hline 8 & 3 & 75 & 1 & 25 & 4 & \\
\hline 10 & 1 & 33 & 2 & 67 & 3 & \\
\hline 11 & 1 & 100 & 0 & 0 & 1 & \\
\hline Sum & 26 & 65 & 14 & 35 & 40 & \\
\hline
\end{tabular}

*Chi square p value.

Table 2. Shows distribution of patients by genre and isolation of $H$. pylori.

\begin{tabular}{cccccccc}
\hline & \multicolumn{5}{c}{ Isolation H. pylori } & & \\
\cline { 2 - 5 } GENRE & NEGATIVE & POSITIVE & Sum & $\begin{array}{c}\mathrm{p} \\
\text { value }\end{array}$ \\
\cline { 2 - 5 } & $\mathrm{n}$ & $\%$ & $\mathrm{n}$ & $\%$ & & \\
\cline { 2 - 5 } FEMALE & 11 & 84 & 2 & 16 & 13 & \\
MALE & 15 & 55 & 12 & 45 & 27 & 0.09 \\
Sum & 26 & 65 & 14 & 35 & 40 & \\
\hline
\end{tabular}

${ }^{*}$ Fisher exact test p value.

Table 3. Shows means age of patients according isolation of $H$. pylori.

\begin{tabular}{|c|c|c|c|c|c|c|c|}
\hline & $\mathrm{n}$ & Mean & Median & Range & \multicolumn{2}{|c|}{ IC: $95 \%$} & $\mathrm{p}$ value \\
\hline Negative & 26 & 5.08 & 5 & 9 & 4.2 & 5.95 & \\
\hline Positive & 14 & 5.86 & 5 & 7 & 4.5 & 7.21 & 0.14 \\
\hline Total & 40 & 5.35 & 5 & 9 & 4.3 & 6.14 & \\
\hline
\end{tabular}

${ }^{*} t$ student $\mathrm{p}$ value. 
y Tecnologia, Centro de Investigacion y Desarrollo en Ciencias de la Salud and the Facultad de Odontologia de la Universidad Autonoma de Nuevo León.

\section{REFERENCES}

[1] García, J.I., Sepúlveda, S. and Noriega-Hoces, L. (2010) Beneficial effect of reduced oxygen concentration with transfer of blastocysts in IVF patients older than 40 years old. Health, 2, 1010-1017.

http://dx.doi.org/10.4236/health.2010.29149

[2] Crew, K.D. and Neugut, A.I. (2006) Epidemiology of gastric cancer. World Journal of Gastroenterology, 12, 354362.

[3] Parsonnet, J., Friedman, G.D., Vandersteen, D.P., Chang, Y., Vogelman, J.H., Orentreich, N. and Sibley, R.K. (1991) Helicobacter pylori infection and the risk of gastric carcinoma. New England Journal of Medicine, 325, 11271131. http://dx.doi.org/10.1056/NEJM199110173251603

[4] Forman, D., Newell, D.G., Fullerton, F., Yarnell, J.W., Stacey, A.R., Wald, N. and Sitas, F. (1991) Association between infection with Helicobacter pylori and risk of gastric cancer: Evidence from a prospective investigation. British Medical Journal, 302, 1302-1305. http://dx.doi.org/10.1136/bmj.302.6788.1302

[5] Nomura, A., Stemmermann, G.N., Chyou, P.H., Kato, I., Perez-Perez, G.I. and Blaser, M.J. (1991) Helicobacter pylori infection and gastric carcinoma among Japanese Americans in Hawaii. New England Journal of Medicine, 325, 1132-1136. http://dx.doi.org/10.1056/NEJM199110173251604

[6] The EUROGAST Study Group (1993) An international association between Helicobacter pylori infection and gastric cancer. Lancet, 341, 1359-1362. http://dx.doi.org/10.1016/0140-6736(93)90938-D

[7] Marshall, B.J. and Warren, J.R. (1984) Unidentified curved bacilli in the stomach of patients with gastritis and peptic ulceration. Lancet, 8390, 1311-1315. http://dx.doi.org/10.1016/S0140-6736(84)91816-6

[8] Lyon: International Agency for Research on Cancer (1994) Schistosomes, Liver Flukes, and Helicobacter pylori. International Agency for Research on Cancer Monograph, 61, 177-240.

[9] Mendall, M.A. and Northfield, T.C. (1995) Transmission of Helicobacter pylori infection. Gut, 37, 1-3. http://dx.doi.org/10.1136/gut.37.1.1

[10] Gottrand, F. (2003) Helicobacter pylori infection: What are the specific questions in childhood? Gastroentérologie clinique et biologique, 27, 484-487.

[11] Anand, P.S., Nandakumar, K. and Shenoy, K.T. (2006) Are dental plaque, poor oral hygiene, and periodontal disease associated with Helicobacter pylori infection? Journal of Periodontology, 77, 692-698. http://dx.doi.org/10.1902/jop.2006.050163

[12] Berroteran, A., Perrone, M., Correnti, M., Cavazza, M.E., Tombazzi, C., Goncalvez, R., et al. (2002) Detection of Helicobacter pylori DNA in the oral cavity and gastroduodenal system of a Venezuelan population. Journal of
Medical Microbiology, 51, 764-770.

[13] Umeda, M., Kobayashi, H., Takeuchi, Y., Hayashi, J., Morotome-Hayashi, Y., Tano, K., et al. (2003) High prevalence of Helicobacter pylori detected by PCR in the oral cavities of periodontics patients. Journal of Periodontology, 74, 129-134.

http://dx.doi.org/10.1902/jop.2003.74.1.129

[14] Asikainen, S., Chen, C. and Slots, J. (1994) Absence of Helicobacter pylori in subgingival samples determined by polymerase chain reaction. Oral Microbiology and Immunology, 9, 318-320. http://dx.doi.org/10.1111/j.1399-302X.1994.tb00079.x

[15] Kignel, S., de Almeida Pina, F., André, E.A., AlvesMayer, M.P. and Birman, E.G. (2005) Occurrence of Helicobacter pylori in dental plaque and saliva of dyspeptic patients. Oral Diseases, 11, 17-21. http://dx.doi.org/10.1111/j.1601-0825.2004.01043.x

[16] Martinez-Gomis, J., Diouf, A., Lakhssassi, N. and Sixou, M. (2006) Absence of Helicobacter pylori in the oral cavity of 10 non-dyspeptic subjects demonstrated by realtime polymerase chain reaction. Oral Microbiology and Immunology, 21, 407-410. http://dx.doi.org/10.1111/j.1399-302X.2006.00295.x

[17] Chelimsky, G. and Zcinn, S. (2002) Enfermedad ulceropéptica en la infancia. Pediatrics in Review, 22, 349-358.

[18] Vandemplas, Y. (2001) The role of Helicobacter pylori in pediatrics. Current Opinion in Infectious Diseases, 14, 315-321. http://dx.doi.org/10.1097/00001432-200106000-00012

[19] Nares-Cisneros, J., Jaramillo-Rodríguez, Y., Martínez-Ordaz, V.A., Velasco-Rodríguez, V.M., Madero, A., Mena-Arias, G. and Manriquez-Covarrubias, L. (2007) Immunochromatographic monoclonal test for detection of Helicobacter pylori antigen in stool is useful in children from highprevalence developing country. Helicobacter, 12, 354358. http://dx.doi.org/10.1111/j.1523-5378.2007.00514.x

[20] Torres, J., Leal-Herrera, Y., Perez-Perez, G., Gomez, A., Camorlinga-Ponce, M., Cedillo-Rivera, R., Tapia-Conyer, R. and Muñoz, O. (1998) A community-based seroepidemiologic study of Helicobacter pylori infection in Mexico. Journal of Infectious Diseases, 178, 1089-1094. http://dx.doi.org/10.1086/515663

[21] Dunn, B.E., Cohen, H. and Blaser, M.J. (1997) Helicobacter pylori. Clinical Microbiology Reviews, 10, 720741.

[22] Bytzer, P., Dahlerup, J.F., Eriksen, J.R., Jarbøl, D.E., Rosenstock, S., Wildt, S. and Danish Society for Gastroenterology (2011) Diagnosis and treatment of Helicobacter pylori infection. Danish Medical Bulletin, 58, C4271.

[23] Lu, J.J., Perng, C.L., Shyu, R.Y., Chen, C.H., Lou, Q., Chong, K.F., et al. (1999) Comparison of five PCR methods for detection of Helicobacter pylori DNA in gastric tissues. Journal of Clinical Microbiology, 37, 772-774.

[24] Sepúlveda, E., Briceño, C., Spencer, M., Quilodrán, S., Brethauer, U., Moreno, J. and Garcia, A. (2008) Detección de Helicobacter pylori en mucosa gástrica y cavidad oral. Gastroenterología latinoamericana, 19, 73-79.

[25] Kim, N., Lim, S.H., Lee, K.H., You, J.Y., Kim, J.M. and Lee, E. (2000) Helicobacter pylori in dental plaque and 
saliva. Korean Journal of Internal Medicine, 15, 187-194.

[26] Song, Q., Haller, B., Ulrich, D., Wichelhaus, A., Adler, G. and Bode, G. (2000) Quantitation of Helicobacter pylori in dental plaque samples by competitive polymerase chain reaction. Journal of Clinical Pathology, 53, 218222. http://dx.doi.org/10.1136/jcp.53.3.218

[27] Morales-Espinosa, R., Fernandez-Presas, A., GonzalezValencia, G., Flores-Hernandez, S., Delgado-Sapien, G., Mendez-Sanchez, J. L., Sanchez-Quezada, E., Muñoz-Pérez, L., Leon-Aguilar, R., Hernandez-Guerrero, J. and Cravioto, A. (2009) Helicobacter pylori in the oral cavity is associated with gastroesophageal disease. Oral Microbiology and Immunology, 24, 464-468.

http://dx.doi.org/10.1111/j.1399-302X.2009.00541.x

[28] Oliveira, A.M., Queiroz, D.M., Rocha, G.A. and Mendes, E.N. (1994) Seroprevalence of Helicobacter pylori infection in children of low socioeconomic level in Belo Ho- rizonte, Brazil. American Journal of Gastroenterology, 89, 2201-2204.

[29] Dowsett, S.A. and Kowolik, M.J. (1998) Oral Helicobacter pylori: Can we stomach it? Critical Reviews in Oral Biology \& Medicine, 14, 226-233. http://dx.doi.org/10.1177/154411130301400307

[30] Paster, B.J. and Dewhirst, F.E. (1988) Phylogeny of campylobacters, wolinellas, Bacteroides gracillis and Bacteroides ureolyticus by $16 \mathrm{~S}$ ribosomal ribonucleic acid sequencing. International Journal of Systematic Bacteriology, 38, 56-62.

http://dx.doi.org/10.1099/00207713-38-1-56

[31] Chong, S.K., Lou, Q., Fitzgerald, J.F. and Lee, C.H. (1999) Evaluation of the 16S rRNA gene PCR with primers Hp1 and Hp2 for detection of Helicobacter pylori. Journal of Clinical Microbiology, 34, 2728-2730. 